\title{
What comes first, democracy or human rights? Saladin Meckled-Garcia*
}

\author{
Department of Political Science, University College London, London, UK
}

Minimalists about human rights hold that a state can have political legitimacy if it protects a basic list of rights and democratic rights do not have to be on that list. In this paper, I consider two arguments from Benhabib against the minimalist view. The first is that a political community cannot be said to have self-determination, which minimalists take to be the value at the heart of legitimacy, without democracy. The second is that even the human rights protections minimalists take to legitimize institutions cannot be had without democracy. These rights can only be adequately interpreted and specified for any social context if the interpreta- tions and specifications result from democratic processes. Here, I bring out some important problems with these arguments and so conclude that they do not represent a robust case for rejecting minimalism.

Keywords: human rights; legitimacy; democracy; interpretation; specification of rights; human rights minimalism

For two pillars of contemporary liberal thought, the relationship between democracy and human rights is, as they say, complicated. In her rich and engaging book, Seyla Benhabib responds to one type of view on this rela- tionship, held by authors like John Rawls, Charles Beitz and Joshua Cohen who are human rights 'minimalists'. They hold that protecting a limited list of human rights is necessary for a state to be legitimate but a right to demo- cratic institutions does not need to feature on that list, hence the minimalist label. Benhabib, on the other hand, holds the radical thesis that democracy is both an intrinsic requirement for political legitimacy and for enjoying human rights. In this short paper, I consider her two central arguments for those conclusions and argue that each falls short of presenting a robust case against minimalism.

Benhabib's first argument is that the very reason minimalists attribute legitimacy to some non-democratic orders - their valuing of self-determination - requires democracy. A society can only have genuine self-determination if it has democratic institutions. There are no plausible empirical examples, Benhabib challenges, of a regime that is both legitimate in the sense of exemplifying self-determination and yet is un-democratic. What would an

*Email: s.meckled-garcia@ucl.ac.uk @ 2014 Taylor \& Francis 
undemocratic society have going for it? Minimalists might stick to their guns, and stress that such societies can at least show concern for their members by protecting human rights. Benhabib's second argument aims to cut off this line of thought by showing that only democratic decision-making can give human rights the kind of specific content needed to apply them concretely. Human rights ideals need to be interpreted in specific social contexts and many inter- pretations might be possible. Yet, the only morally legitimate way to settle which of these should be applied is by democratic deliberation. If democracy is needed to give concrete content to human rights, then human rights cannot be minimal sources of legitimacy; democracy must come first as a source of legitimacy in a political order.

Both arguments are problematic. Whilst democratic social arrangements might epitomize egalitarian justice, the best account of justice, distributive or political, is not obviously the right threshold for legitimacy. A number of theo- rists have attempted to articulate the idea of a community that is concerned enough for its members, pursuing a common good conception of justice and seeking to collectively arrive at just arrangements, to act legitimately even if it gets it wrong about what justice ultimately demands. Legitimacy is not the value of correctly allocating all distributive and political rights in line with the best account of equality. It is the value of having the social warrant to pursue a communal answer to the question of what equality requires. Full-blown political equality, of which democracy will be a part, is an account of what political arrangements best exemplify equality. The question is whether a society might get it wrong about the best account of political equality and still have social war- rant to try to get it right about that and justice more generally. Plausibly, protect- ing fundamental human rights shows sufficient communal concern for citizens to set a threshold above which fallibility on the justice question is permitted. Benhabib problematically runs together justice and legitimacy, an equivalence that minimalists reject, and that elision makes her case for democracy as the threshold for legitimacy plausible. Benhabib's second argument is that giving any concrete content to human rights necessarily requires democratic deliberation. Against this, I argue that the claim relies on an elision between rights that can be legitimately pursued in a society and those rights we have in principle. Societies can legitimate pursue the wrong content for some rights, such as those of justice. But that does not mean human rights fail in principle to have an objec- tively right content, independently of what society legitimately decides. A plausi- ble role for human rights is to set the limits on how wrong a society can go.

Benhabib defines democracy in terms of respect for democratic rights, rather than in terms of processes (Benhabib 2011, p. 79 - page numbers in text will refer to Benhabib 2011 from now on, unless otherwise stated). These rights, constituting the 'right to have rights', include rights to life, liberty, personal property, equal freedom of thought; freedom of expression and association, and rights to representation, self-government and 
some basic bundle of socio- economic goods (p. 127). They are morally valuable because they recognise

Critical Review of International Social and Political Philosophy 683

persons as worthy of equal concern and as having a status worthy of protection by their polity and world community (pp. 60,62). They protect individuals' 'communicative freedom': the ability to freely and equally engage in collective deliberations and decisions on the social rules under which they should live under (pp. 60, 68, 71). Social rules emanating from free deliberation under such a scheme of rights and only rules emanating from such collective deliberation are, in Benhabib's view, legitimate (pp. 67, $69,74)$. In this way democracy legi- timates the imposition of social requirements.

It seems reasonable to hold that the concepts of justice and political legiti- macy are distinct. After all, how can social institutions even attempt to dis- cover or achieve a just social arrangement without the social warrant to embark on that project? Surely, too, societies must be allowed some degree of fallibility in their attempts at just arrangements, so long as these attempts do not undermine the very point of trying: concern for the lives of their members. Some theorists have, for this reason, proposed a distinction between the grounds for legitimate political rule and the justice of political arrangements. The moral value underpinning legitimate rule is distinct from the values under- pinning justice; the warrant to exercise social power in seeking just arrange- ments can have something going for it even if it falls short of the realisation of justice. Of course, the very same value underpinning legitimacy must place limits on what can be socially authorised; arbitrary or seriously wrongful exer- cises of power will have nothing going for them at all. If one accepts this legit- imacy-justice distinction, then some social measures can count as legitimate, carrying moral authority for those subject to them, without necessarily being fully just. A government can have the social warrant to pursue social measures, so long as they do not fall below the minimum threshold of legitimacy, even if the motivation behind those measures is a mistaken notion of what justice demands.

Minimalist theorists have developed conditions for legitimacy understood in this way. They also, however, distinguish legitimacy from democracy, in that their minimal conditions of legitimacy do not contain democratic rights. For example, Rawls proposes that to have one kind of legitimacy: to merit recogni- tion as a polity with the right to freely create laws and engage in relations with other states, a society must satisfy conditions of well-orderedness (Rawls 2001, pp. 64-67). These include protections for a basic list of human rights, a working legal system in which the rule of law operates, with judges applying a common good conception of justice, and some mechanism for consulting citizens as to their views on government decisions, though not necessarily a democratic mech- anism. Dworkin similarly proposes that protection of a schedule of human rights for citizens is a legitimacy threshold for a state (Dworkin 2011, pp. 335ff.). 
Benhabib specifically targets Rawls, Beitz and Cohen, as minimalist theo- rists. For Beitz, the point of human rights is to see the threshold for legitimacy that trumps external international intervention in the affairs of a state. Regimes can satisfy such a threshold without protecting fully democratic rights

\section{S. Meckled-Garcia}

(Beitz 2009, p. 189). Presumably, this is because self-determination can be served without democracy properly speaking (Beitz 2009, p. 183). Cohen holds that so long as certain conditions necessary for self-determination are in place, a state can be legitimate without being democratic (Cohen 2004, Benhabib 2011, p. 85). The conditions are that political decisions arise from, and are accountable to, processes in which everyone's interests are represented; there are rights to dissent for all; and public officials justify decisions in terms of a widely held notion of the common good. The values underpinning legitimacy here are those of membership and inclusion (Cohen 2004, p. 213).

Benhabib's rejection of minimalist conceptions of legitimacy is based on the claim that only a society with democratic rights can truly exhibit self- determination, or the values underpinning it (pp. 78, 85). Furthermore, she challenges minimalists to give any empirical example of a society that does not protect democratic rights, or 'democratic equality' (p. 78), and can yet be said to express the values underpinning selfdetermination (p. 85). Indeed, Benhabib charges that minimalist tests for legitimacy are likely to pass unsa- voury types of regime, paternalisms and benevolent despotisms (pp. 85,87 ). In the Rawlsian version of minimalism, regimes that deny equal freedoms (of religion, of expression and association, of minorities and of women) will also pass the legitimacy test (p. 88). For this critique to work, Benhabib needs to hold that no plausible moral value we might offer as underpinning legitimacy can be served by undemocratic social arrangements.

It is true that paternalist government or benevolent despotisms are not the best expressions of, say, political equality. But the legitimacy question is not about the best form of government, as a matter of egalitarian social arrange- ments. Rather it asks whether a form of government, including these imperfect forms, can be warranted, morally, to act politically. That threshold would have to be set by a different value than that of having already got it right about fully fledged political equality. Consider the value of having a community in which there is genuine concern for fellow community members, even where ideas about decision-making and authority are confused. A traditional society where decisions are left to elders, or those with supposed accumulated wisdom, does not seem automatically to signal the absence of communal concern. Of course some indicator is needed that there is communal concern for members of a society, and it is plausible that human rights and some mechanisms for deliber- ation should play this role. They, after all, protect individuals from the kind of interference to 
which tyrannies resort in order to avoid losing power and maintain enforced social cohesion.

Benhabib challenges that we are hard pressed to find empirical examples of societies that are both non-democratic and plausibly legitimate. Yet, this may simply be because empirically, societies without democratic rights tend to be societies that do not respect key human rights. Moreover, perhaps legitimacy is not an all-or-nothing quality of a society. Those laws in a society that do respect rights upholding minimal communal concern, even if not democratically

\section{Critical Review of International Social and Political Philosophy 685}

established, could be said to legitimately uphold the rule of law. A monarchy might institute habeas corpus, and it is not obvious that this initiative is illegiti- mate. To the extent that key human rights are protected in such societies they can be said to exhibit values like communality, mutual concern or a genuine col- lective commitment to achieving justice. Getting it wrong about justice, includ- ing the justice of full political equality, is not sufficient for absence of communal concern, and so is not sufficient for illegitimacy. The minimalist case, being built on human rights exhibiting communal concern, then, is not touched by the critique.

Benhabib's second argument, if successful, would cut off this minimalist case at the root. It is that one cannot even have human rights without democ- racy. For any social context, the specification of moral equality through human rights depends intrinsically on there being democratic law-giving institutions (p. 127). Basic access to social rights requires that human rights be realised and specified in law (pp. 62, 68). In fact she claims, contra Sen, that human rights proper only exist when moral rights are translated into justiciable duties in a legal system (p. 82). Furthermore, the realisation of human rights neces- sarily requires an interpretation of those rights, and one according to the social context in which they will be applied (pp. 74, 88, 125, 128). So there will be variation in the specification of the rights, but the only variation that can be legitimate is that arrived at through democratic deliberation. This variation is not an option but an intrinsic part of working out what human rights mean beyond very abstract statements (pp. 74, 127). So democratic legitimation is not optional - it is intrinsic to legitimately varying the content of human rights.

If this argument is right, then human rights cannot be a minimal source of legitimacy given that, to be legitimate, the varying interpretations through which they are realised must be underwritten by a democratic procedure. In fact, in order to have human rights at all beyond 'hollow' ideals one needs democratic procedures that legitimately interpret and apply them as social rules (pp. $68,73,74,82,125$ ). 
Now, it is important to clarify how this argument works. The reason that human rights are said to be reliant on democratic deliberation is that to move from abstract principles to justiciable social rules the former must be inter- preted and interpreted with due regard to the social context (pp. 74, 80). There are two possible senses of contextual interpretation that matter here. Either the interpretation is sensitive to objective contextual features such as conditions and resources, or the interpretation must be sensitive to subjective contextual features such as the shared views or understandings of the political community. Benhabib seems to mean the latter as the contextual basis for varying the content of human rights standards (pp. 71, 74, 80). This also fits the claim that only democratic deliberation, with people freely arriving at a collective interpretation, can result in legitimate variation on how to apply the abstract principles. If variations in the content of human rights result from free

\section{S. Meckled-Garcia}

deliberation then those variations are due to the views, opinions and judge- ments of the deliberators. No instructions accompany free deliberation, con- straining what direction it should take (which is what it means to say that democratic deliberation is prior to human rights). If variation tracked objective contextual features, then the variations resulting from democratic deliberation would not necessarily offer the right interpretation of the content of the rights. Democracies could get it wrong about the relevant contextual differences.

There are two problems with this argument. The first is that it does not entail the conclusion Benhabib wants: the priority of democracy. Given that genuine legitimacyimparting deliberation is defined in terms of a set of rights, the 'right to have rights', then those rights too will be subject to variation. Varying interpretations will need legitimating. In order to know whether a state genuinely exemplifies democracy-based legitimacy, then, we will need to know whether its governing interpretation of democratic rights is itself legitimate - an acceptable riff on an abstract ideal. The only way round this whilst still holding the variation thesis would be to argue that democracy-defining rights are different from other rights in not requiring contextual application and inter- pretation. This seems implausible. There is no obvious feature of such rights, and Benhabib presents none, to single them out as especially 'self-interpreting'. In fact her account of the right to have rights, see above, is a somewhat extensive subset of the standard human rights list plus rights to democratic decision-making processes (p. 127). One might say the content of these rights is given by their clear moral purpose: free, collective and deliberative decision- making (communicative freedom). But any morally justified right will have a clear moral purpose, at least in the sense of serving a moral value. If rights can only have concrete content through legitimate variation, democracy is not prior to human rights as democracy is itself defined in terms of rights.

One could answer that we need to start somewhere, and that developing a specification of democratic rights, including the democratic ones, is a herme- neutic process - a back- 
and-forth discussion that has to have a starting point, albeit with tentative and revisable first steps (p. 71). But given the steps are those being made by a social order in relation to citizens, we need to know when a first, or any, step in that process is legitimate and democracy was offered as a candidate solution for this problem.

The second problem with this argument is that it runs together the justified content of rights with their legitimate application in a polity. The claim that without legitimate variation human rights cannot have determinate content implies, as it were, that the meaning of human rights consists in whatever dif- ferent 'democratic variations' decide it is, and nothing more. But if human rights are expressible as moral principles then all variations will have one thing in common: that they fit the principles. The right to freedom from slav- ery, for example, will vary in its application given what we take ownership over persons to mean, and our understanding of that might develop over time; we might come to understand that human trafficking is an example of treating

\section{Critical Review of International Social and Political Philosophy 687}

persons as property. But the cases covered by the right will have one thing in common: that they deal with treating persons as property. Or take a socio- economic right, like claims to health insurance. What counts as wrongful in terms of health insurance provisions will vary with the available resources and associated burdens of providing it. What constitutes a genuinely available resource or acceptable burden (say in the form of taxes) morally speaking will itself depend on principles of fair or reasonable trade-offs between benefits (health provisions) and tax burdens (see Meckled-Garcia 2013, pp. $77 \mathrm{ff}$.). That may vary from society to society. It may require a degree of interpretation on a case-by-case basis, as to whether a given burden is reasonable. But none of that means that the only correct interpretations are those endorsed by the demos. On the contrary, they are valid when they fit the principles, and fail to be valid when they do not, which is a general interpretative matter on which the view of the demos is just one among others. Nothing in collective delibera- tion guarantees infallibility. Of course, if one thinks there can be no right answer as to how to interpret moral principles, then any answer is as right as the next. But I assume Benhabib is not engaged in that kind of scepticism, and even if she were it would still not give priority to the democratic answer which would merely be one answer among many.

All that aside, there is the wholly different question of whether one or other given interpretation should be decisive as a matter of legal and social arrangements. Of course that question depends on decision-making procedures in a society and decision-making procedures can be legitimate or illegitimate. Whatever the correct interpretation of a right might be, in a social context other imperatives will rightly influence what interpretation we must collectively accept as authoritative. There is the question of what is socially achievable given current understandings and how to adjudicate disputes over interpreta- 
tions so that the rule of law prevails. Both considerations might vary which interpretation of a right ought to prevail in different political communities. Yet, when a variation reaches beyond certain limits one must say that it is not even an attempt show communal concern for members, and then legitimacy, not only justice, is in jeopardy.

The moral aim of legitimacy is to describe the limits within which political communities can vary on their understanding of justice and outside of which we are lead to question whether we have political community (as opposed to tyranny and rule by violence) at all. Justice concerns what fully fledged social equality might demand, and that will include theories of equality in social deliberation. Getting it wrong about justice, or the ideal of political equality, need not mean getting it so wrong as to make our institutions illegitimate. Benhabib's argument is that the best theory of political equality, democracy, is the only viable account of legitimacy, but that argument conflates the demands of justice with the conditions for legitimately trying to get justice right.

\section{S. Meckled-Garcia Notes on contributor}

Saladin Meckled-Garcia is lecturer in Human Rights and Political Theory, in the Depart- ment of Political Science at University College London. He is also co-director of the UCL Institute for Human Rights. He has published articles on human rights, social justice and equality in a number of venues including the Journal of Political Philosophy, the Journal of Applied Philosophy, Proceedings of the Aristotelian Society, and Review of International Studies.

\section{References}

Beitz, Charles, 2009. The idea of human rights. Oxford: Oxford University Press. Benhabib, S., 2011. Dignity in adversity: human rights in troubled times. Cambridge:

Polity Press. Cohen, Joshua, 2004. Minimalism about human rights: the most we can hope for?

Journal of political philosophy, 12, 190-213. Dworkin, R., 2011. Justice for hedgehogs. Cambridge, MA: Belknap press. Meckled-Garcia, S., 2013. Giving up the goods: rethinking the human rights to

subsistence, institutional justice, and imperfect duties. Journal of applied philosophy,

30, 73-87. Rawls, John, 2001. The law of peoples. Cambridge, MA: Harvard University Press. 